\title{
Performance of faba bean genotypes with Orobanche foetida Poir. and Orobanche crenata Forsk. infestation in Tunisia
}

\author{
Imen Trabelsi ${ }^{1 *}$, Zouhaier Abbes ${ }^{1}$, Moez Amri ${ }^{2}$, and Mohamed Kharrat ${ }^{1,3}$
}

\begin{abstract}
Orobanche foetida Poir. and O. crenata Forsk. are major constraints to faba bean (Vicia faba L.) cultivation in Tunisia. To evaluate the different levels of resistance of seven small-seeded faba bean genotypes to these parasitic weed species, three trials were conducted in fields infested and non-infested with O.foetida in the Oued Beja Agricultural Experimental Unit and $O$. crenata in an experimental field at Ariana of the National Institute of Agricultural Research during three cropping seasons. Compared to the susceptible cv. Badi, the seven genotypes showed moderate to high levels of resistance to both Orobanche species. The number and dry weight of emerged broomrapes and underground tubercles recorded on the new improved genotypes were lower than those recorded on released and resistant 'Najeh' and 'Baraca'. The parasitism index on the new genotypes varied from 2-6 times less than susceptible 'Badi' in both Oued-Beja and Ariana. Yield reduction due to O.foetida infection varied from $13.5 \%$ on genotype XAR-VF00.13-89-2-1-1-1-1 to 59.7\% on 'Baraca', whereas the yield loss was about $92 \%$ on the susceptible control. Parasitic infection did not affect dry grain protein accumulation in the tested genotypes.
\end{abstract}

Key words: Broomrape, Vicia faba, resistance, Tunisia.

\section{INTRODUCTION}

Orobanche species (broomrapes) are chlorophyll-lacking root parasites of many cultivated crops such as legumes, sunflower, and tobacco (Joel et al., 2007; Parker, 2012). The total infested areas in Tunisia vary from 5000 to 10000 ha (Kharrat and Souissi, 2004) for legumes. In many infested fields, farmers avoid growing faba bean (Vicia faba L.) and other susceptible crops, resulting in substantial reductions of both grain production and cultivated areas (Kharrat and Souissi, 2004). Infestation by broomrape has been also reported on Lathyrus odoratus L., grass pea (L. sativus L.), Trifolium alexandrinum L., Medicago truncatula Gaertn., and V. sativa L. subsp. amphicarpa (L.) Batt. in Tunisia (Kharrat, 2002a). Orobanche crenata Forsk. has parasitized a wide host range since antiquity, e.g. faba bean, pea (Pisum sativum L.), lentil (Lens culinaris Medik.), vetch ( V. sativa), grass pea, and forage legumes (Rubiales et al., 2006); it causes great damage to faba bean crops and

${ }^{1}$ Carthage University, National Institute for Agricultural Research of Tunisia (INRAT), Rue Hédi Karray, 2080 Ariana, Tunisia. *Corresponding author (trabelsiimen11@yahoo.fr).

${ }^{2}$ Carthage University, Regional Field Crop Research Center of Beja (CRRGC), Route de Tunis, km 5, 9000 Béja, Tunisia.

${ }^{3}$ International Center for Agricultural Research in the Dry Areas (ICARDA), Rabat Office Av. Mohamed Belarbi Alaoui, P.O. Box 6299, Rabat-Institute, Rabat, Morocco.

Received: 21 June 2014.

Accepted: 14 October 2014.

doi:10.4067/S0718-58392015000100004 notable yield losses. In Tunisia, faba bean is infested by two Orobanche species, O. foetida Poir. and O. crenata. The latter is mainly distributed in eastern Tunisia while the former is restricted to the western and north central areas especially the Beja region (Kharrat and Halila, 1994). Fetid broomrape ( $O$. foetida) constitutes a serious threat mainly to faba bean cultivation and causes yield losses of $66 \%$ $83 \%$ (Abbes et al., 2008). Only peas among grain legumes escape O.foetida attacks (Kharrat, 1999).

Various cultural and chemical strategies have been used to control O. foetida (Kharrat and Halila, 1994; Abbes et al., 2010a) and O. crenata (El-Shirbini and Mamdouh, 2004; Pérez-de-Luque et al., 2004b) on faba bean. Unfortunately, most of them alone are not effective or have insufficient success due to the longevity in soil, small size, and high fecundity of Orobanche seed (DíazRuiz et al., 2009). An integrated control strategy based on the use of resistant varieties remains the most likely economical and feasible control method (Pérez de-Luque et al., 2010; Maalouf et al., 2011). In Tunisia, research activities on Orobanche parasitic weeds has intensified since the 1990s, mainly on faba bean in order to select new high-yielding faba bean varieties locally adapted to the Tunisian environment and resistant to both $O$. foetida and $O$. crenata. The national faba bean program released the first partially resistant faba bean cultivar ('Najeh') in 2009 (Kharrat et al., 2010) and registered it in the Tunisian Official Catalogue of Plant Variety.

This study aimed to examine the degree of resistance of seven faba bean genotypes selected for their 
resistance to $O$. foetida and $O$. crenata and to determine the effects of broomrape infestation on crop productivity and quality in reference to partially resistant cultivars Najeh and Baraca and susceptible ('Badï') in diverse environments.

\section{MATERIALS AND METHODS}

Ten faba bean genotypes were evaluated against both Orobanche spp., seven advanced lines and three released varieties: 'Badi' as the susceptible control and 'Najeh' and 'Baraca' as partially resistant controls (Table 1).

The trials for evaluating genotypes for resistance to $O$. foetida were conducted during three consecutive cropping seasons (2009-2012) in both heavily Orobancheinfested and non-infested soils at Oued Beja Agricultural Experimental Unit $\left(36^{\circ} 44^{\prime} \mathrm{N}\right.$; 9 $9^{\circ} 13^{\prime} \mathrm{E} ; 150 \mathrm{~m}$ a.s.1.) in north-west Tunisia in a sub-humid climate with moderate winters (average annual rainfall of $600 \mathrm{~mm}$ ). The monthly rainfall and average temperature distribution for the three cropping seasons are presented in Figure 1. The genotypes were evaluated in a randomized complete block design with three replicates. Each plot consisted of four rows of $4 \mathrm{~m}$ length and $0.5 \mathrm{~m}$ inter-row spacing $\left(8 \mathrm{~m}^{2}\right)$. During the three cropping seasons, sowing was during the first week of December with a seeding rate of 24 seeds $\mathrm{m}^{-2}$.

The 10 genotypes were also evaluated for resistance to $O$. crenata in an infested field in the National Institute of Agricultural Research (INRAT) experimental field at Ariana $\left(36^{\circ} 50^{\prime} \mathrm{N}, 10^{\circ} 11^{\prime} \mathrm{E}\right.$; $7 \mathrm{~m}$ a.s.1.) The trial was a randomized complete block design with three replicates, and each genotype was sown during the first week of December in a single row of $4 \mathrm{~m}$ length and an inter-row spacing of $0.3 \mathrm{~m}\left(1.2 \mathrm{~m}^{2}\right)$.

Table 1. Pedigree, origin, and main characteristics of studied faba bean genotypes.

\begin{tabular}{ll}
\hline Genotype/Pedigree & \\
\hline G1: XAR-VF00.12-12-3-1-3-1 & Crigin/characteristics \\
G2: XAR-VF00.13-8-3-1-1-1-1 & Cross performed in Tunisia (Ariana) in 2000 \\
G3: XAR-VF00.13-89-2-1-1-1-1 & Cross performed in Tunisia (Ariana) in 2000 \\
G4: XBJ92.10-27-1-1-1-1-1 & Cross performed in Tunisia (Oued Beja) in 1992 \\
G5: XBJ92-10-46-1-3-1-2-1-1-6-A & Cross performed in Tunisia (Oued Beja) in 1992 \\
G6: XBJ90.04-6-2-1-1-4-C & Cross performed in Tunisia (Oued Beja) in 1990 \\
G7: XBJ90.04-2-3-1-1-1-2A & Cross performed in Tunisia (Oued Beja) in 1990 \\
G8: 'Baraca' & Spain/Partially resistant to Orobanche crenata \\
G9: 'Najeh' & Small-seeded variety released in 2009/Partially resistant to Orobanche foetida and O. crenata \\
G10: 'Badi' & Small-seeded variety released in 2004/Susceptible to O.foetida and O. crenata \\
\hline
\end{tabular}

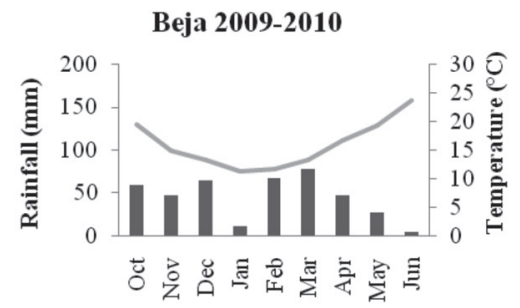

Beja 2010-2011

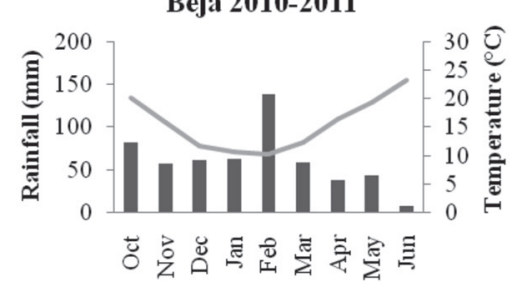

Beja 2011-2012

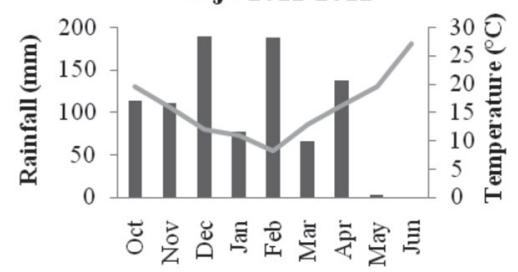

Ariana 2009-2010
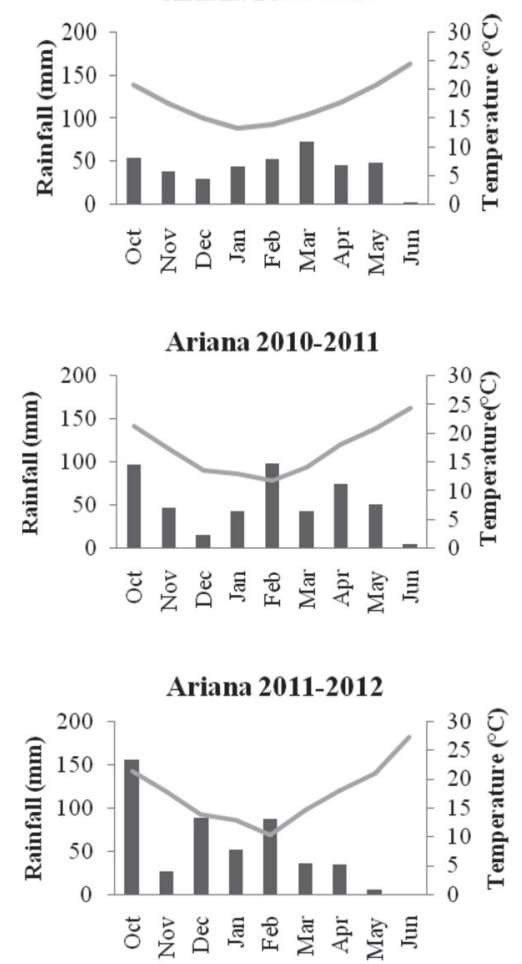

Figure 1. Monthly average temperature $\left({ }^{\circ} \mathrm{C}\right)$ and precipitation $(\mathrm{mm})$ during the three cropping seasons of 2009-2010, 2010-2011, and 2011-2012 in two experimental stations (Oued Beja and Ariana, Tunisia). 


\section{Data collection and analyses}

Resistance/susceptibility levels of faba bean lines were determined using several parameters on three randomly selected plants, from each plot, at two growth stages (pod setting and maturity). At pod setting stage, the number of emerged and non-emerged Orobanche and total Orobanche dry weight per plant were recorded. The Orobanche were classified according to their development stages using a 1-5 scale (Labrousse et al., 2001): $1=$ attachment of haustoria to host root, $2=$ small tubercles without root development, $3=$ tubercles with crown roots without shoot formation, $4=$ underground tubercles with shoot formation and $5=$ emergence of spikes. The dry weight was measured after drying fresh samples at $80^{\circ} \mathrm{C}$ for $48 \mathrm{~h}$. At maturity stage, the following parameters were recorded on the two central rows at Oued Beja and one single row at Ariana: number of Orobanche shoots, total Orobanche dry weight, Orobanche incidence (percentage of faba bean plants presenting emerged Orobanche shoots per plot), Orobanche severity using a 1-9 scale (Abbes et al., 2007a), parasitism index $=($ incidence $\times$ severity $) / 100$, grain yield, 100 seed weight, and protein content. The $\mathrm{N}$ percentage (NP) was determined using $100 \mathrm{mg}$ of dried milled faba bean seed infested or not by $O$. foetida using the micro-Kjeldahl method (AOAC, 1975). The protein content was calculated from NP $\times 6.25$.

ANOVA was performed using the SPSS statistical program v.15 (IBM Corporation, Armonk, New York, USA). Mean comparisons were made using Duncan's multiple-range test at $P=0.05$.

\section{RESULTS AND DISCUSSION}

There were highly significant differences among genotypes in response to $O$. foetida and $O$. crenata for most studied parameters. In the three cropping seasons, genotypes showed parasitism indexes in the range of 1-4.1 compared to 6.9 for susceptible 'Badi'' in fields infested by $O$. foetida, and correspondingly 0.7-2.4 compared to 6.9 for $O$. crenata infestation (Table 2). Orobanche severity and incidence were significantly lower (both $P$ $<0.001$ ) for the selected genotypes than the susceptible control 'Badï'. Incidence was estimated to be close to
$100 \%$ in both Oued Beja and Ariana infested fields for 'Badï', indicating uniform infestation of both sites. Nevertheless, and without considering the susceptible control, the incidence was $32 \%-84 \%$ at Oued Beja for $O$. foetida infestation and $25 \%-59 \%$ at Ariana for $O$. crenata infestation. Of tested lines, 'Badï' presented the highest severity $(>7)$ for both Orobanche species. The parasitism index (which integrates both parameters) gives an accurate level of resistance of the tested genotypes and enabled classifying the studied genotypes into three groups: the first included the susceptible 'Badï' which was the most affected by $O$. foetida and $O$. crenata, with the highest parasitism index (Table 2); the second group included genotypes with intermediate resistance to $O$. foetida ('Baraca', G4, and G5) and O. crenata (G1, G4, and 'Baraca'); and the last, with lower parasitism index were G6, G7, G3, G1, G2, and 'Najeh' for $O$. foetida and G5, G6, G7, 'Najeh', G3, and G2 for O. crenata, had the highest resistance.

Highly significant differences $(P<0.001)$ were observed among genotypes for the number of Orobanche shoots per faba bean plant at maturity stage (Table 3 ). The lowest numbers of Orobanche shoots per plant were for genotypes G6, G7, 'Najeh', G3, G5, and G2 with $O$. foetida infestation and G5, G6, G7, 'Najeh', G3, G2, and G4 with $O$. crenata infestation, whereas 'Badi'' had 2.3 and 4.2 shoots per plant, respectively. The variation in infestation level among different seasons can be explained by the specific climatic conditions of each season. Based on average results of the three seasons, the total number of emerged Orobanche shoots per plant and Orobanche dry weight (Table 4) were significantly (both $P<0.001$ ) lower than 'Badii' for the selected genotypes. Among the tested genotypes, G6 was slightly infested by both Orobanche species and showed the lowest number and dry weight of Orobanche for both species.

Evaluations of non-emerged (underground) attachments at faba bean pod setting stage showed further differences that were not detectable when only the number of emerged broomrapes was considered at the maturity stage. At pod setting there were significant differences $(P<0.001)$ between studied genotypes (Figure 2). Among the genotypes, G6 showed the lowest infection level by

Table 2. Estimated parasitism index recorded for faba bean genotypes during the cropping seasons 2009-2010, 2010-2011, and 2011-2012.

\begin{tabular}{|c|c|c|c|c|c|c|c|c|}
\hline \multirow[b]{2}{*}{ Genotypes } & \multicolumn{3}{|c|}{ Orobanche foetida-Oued Beja } & \multirow[b]{2}{*}{ Mean } & \multicolumn{3}{|c|}{ Orobanche crenata-Ariana } & \multirow[b]{2}{*}{ Mean } \\
\hline & 2009-2010 & 2010-2011 & 2011-2012 & & 2009-2010 & 2010-2011 & 2011-2012 & \\
\hline G1 & $2.2 \mathrm{ab}^{*}$ & $1.0 \mathrm{a}$ & $4.1 \mathrm{bc}$ & $2.5 \mathrm{ab}$ & $2.7 \mathrm{ab}$ & $3.1 \mathrm{a}$ & $0.9 \mathrm{ab}$ & $2.3 \mathrm{bc}$ \\
\hline $\mathrm{G} 2$ & $3.3 \mathrm{ab}$ & $0.3 \mathrm{a}$ & $3.8 \mathrm{abc}$ & $2.5 \mathrm{ab}$ & $1.9 \mathrm{ab}$ & $2.9 \mathrm{a}$ & $0.1 \mathrm{a}$ & $1.8 \mathrm{ab}$ \\
\hline G3 & $1.1 \mathrm{a}$ & $1.0 \mathrm{a}$ & $3.3 \mathrm{abc}$ & $1.9 \mathrm{ab}$ & $1.9 \mathrm{ab}$ & $2.4 \mathrm{a}$ & $0.1 \mathrm{a}$ & $1.6 \mathrm{ab}$ \\
\hline G4 & $4.2 \mathrm{bc}$ & $1.9 \mathrm{ab}$ & $5.8 \mathrm{bcd}$ & $4.1 \mathrm{~cd}$ & $3.3 b$ & $2.1 \mathrm{a}$ & $1.4 \mathrm{~b}$ & $2.4 \mathrm{bc}$ \\
\hline G5 & $3.0 \mathrm{ab}$ & $1.8 \mathrm{ab}$ & $4.7 \mathrm{bcd}$ & $3.2 \mathrm{bc}$ & $0.4 \mathrm{a}$ & $1.4 \mathrm{a}$ & $0.0 \mathrm{a}$ & $0.7 \mathrm{a}$ \\
\hline G6 & $1.4 \mathrm{a}$ & $0.7 \mathrm{a}$ & $1.0 \mathrm{a}$ & $1.0 \mathrm{a}$ & $0.4 \mathrm{a}$ & $1.5 \mathrm{a}$ & $0.0 \mathrm{a}$ & $0.8 \mathrm{a}$ \\
\hline G7 & $1.2 \mathrm{a}$ & $0.4 \mathrm{a}$ & $2.9 \mathrm{ab}$ & $1.5 \mathrm{a}$ & $0.7 \mathrm{a}$ & $1.4 \mathrm{a}$ & $0.0 \mathrm{a}$ & $0.8 \mathrm{a}$ \\
\hline 'Baraca' & $5.3 \mathrm{bc}$ & $3.5 b$ & $6.3 \mathrm{~cd}$ & $5.0 \mathrm{~d}$ & $1.8 \mathrm{ab}$ & $4.7 b$ & $1.7 \mathrm{~b}$ & $3.0 \mathrm{c}$ \\
\hline ‘Najeh’ & $2.8 \mathrm{ab}$ & $1.5 \mathrm{a}$ & $3.3 \mathrm{abc}$ & $2.6 a b$ & $1.5 \mathrm{ab}$ & $2.1 \mathrm{a}$ & $0.0 \mathrm{a}$ & $1.3 \mathrm{ab}$ \\
\hline 'Badï' & $6.8 \mathrm{c}$ & $6.3 \mathrm{c}$ & $7.6 \mathrm{~d}$ & $6.9 \mathrm{e}$ & $6.5 \mathrm{c}$ & $8.5 \mathrm{c}$ & $5.2 \mathrm{c}$ & $6.9 \mathrm{~d}$ \\
\hline
\end{tabular}

Data with the same letter per column are not significantly different according to Duncan's test $(P=0.05)$. 
Table 3. Number of emerged Orobanche at crop maturity for faba bean genotypes during cropping seasons 2009-2010, 2010-2011, and 20112012.

\begin{tabular}{|c|c|c|c|c|c|c|c|c|}
\hline \multirow[b]{2}{*}{ Genotypes } & \multicolumn{3}{|c|}{ Orobanche foetida-Oued Beja } & \multirow[b]{2}{*}{ Mean } & \multicolumn{3}{|c|}{ Orobanche crenata-Ariana } & \multirow[b]{2}{*}{ Mean } \\
\hline & $2009-2010$ & 2010-2011 & 2011-2012 & & $2009-2010$ & 2010-2011 & 2011-2012 & \\
\hline G1 & $2.1 \mathrm{a}^{*}$ & $0.4 \mathrm{bc}$ & $2.4 \mathrm{c}$ & $1.6 \mathrm{cde}$ & $1.6 \mathrm{a}$ & $2.8 \mathrm{abc}$ & $0.4 \mathrm{a}$ & $1.7 \mathrm{~b}$ \\
\hline G2 & $2.3 \mathrm{a}$ & $0.0 \mathrm{a}$ & $1.6 \mathrm{abc}$ & 1.3abcd & $1.8 \mathrm{a}$ & $1.8 \mathrm{ab}$ & $0.0 \mathrm{a}$ & $1.2 \mathrm{ab}$ \\
\hline G3 & $1.3 \mathrm{a}$ & $0.2 \mathrm{ab}$ & $1.4 \mathrm{abc}$ & $0.9 \mathrm{abc}$ & $1.4 \mathrm{a}$ & $1.3 \mathrm{ab}$ & $0.0 \mathrm{a}$ & $0.9 \mathrm{ab}$ \\
\hline G4 & $1.8 \mathrm{a}$ & $0.5 \mathrm{c}$ & $2.0 \mathrm{bc}$ & $1.4 \mathrm{bcd}$ & $1.7 \mathrm{a}$ & $1.5 \mathrm{abc}$ & $0.4 \mathrm{a}$ & $1.5 \mathrm{ab}$ \\
\hline G5 & $1.4 \mathrm{a}$ & $0.3 \mathrm{abc}$ & $2.0 \mathrm{bc}$ & $1.2 \mathrm{abcd}$ & $0.1 \mathrm{a}$ & $0.7 \mathrm{a}$ & $0.0 \mathrm{a}$ & $0.3 \mathrm{a}$ \\
\hline G6 & $1.4 \mathrm{a}$ & $0.2 \mathrm{abc}$ & $0.3 \mathrm{a}$ & $0.7 \mathrm{a}$ & $0.2 \mathrm{a}$ & $0.8 \mathrm{a}$ & $0.0 \mathrm{a}$ & $0.5 \mathrm{a}$ \\
\hline G7 & $0.9 \mathrm{a}$ & $0.3 \mathrm{ab}$ & $1.1 \mathrm{abc}$ & $0.8 \mathrm{ab}$ & $0.4 \mathrm{a}$ & $1.0 \mathrm{a}$ & $0.0 \mathrm{a}$ & $0.5 \mathrm{a}$ \\
\hline 'Baraca' & $2.6 \mathrm{a}$ & $1.1 \mathrm{~d}$ & $1.5 \mathrm{abc}$ & $1.8 \mathrm{ab}$ & $0.9 \mathrm{a}$ & $3.6 \mathrm{bc}$ & $0.5 \mathrm{a}$ & $2.0 \mathrm{~b}$ \\
\hline 'Najeh' & $1.2 \mathrm{a}$ & $0.2 \mathrm{abc}$ & $0.9 \mathrm{ab}$ & $0.8 \mathrm{ab}$ & $0.7 \mathrm{a}$ & $1.5 \mathrm{ab}$ & $0.0 \mathrm{a}$ & $0.9 \mathrm{ab}$ \\
\hline ‘Badï' & $2.8 \mathrm{a}$ & $2.1 \mathrm{e}$ & $1.8 \mathrm{bc}$ & $2.3 \mathrm{e}$ & $4.5 b$ & $4.5 c$ & $3.7 \mathrm{~b}$ & $4.2 \mathrm{c}$ \\
\hline
\end{tabular}

Data with the same letter per column are not significantly different according to Duncan's test $(P=0.05)$.

Table 4. Total dry weights (g) of emerged Orobanche per plant at crop maturity for faba bean genotypes during cropping seasons 2009-2010, 2010-2011, and 2011-2012.

\begin{tabular}{|c|c|c|c|c|c|c|c|c|}
\hline \multirow[b]{2}{*}{ Genotypes } & \multicolumn{3}{|c|}{ Orobanche foetida-Oued Beja } & \multirow[b]{2}{*}{ Mean } & \multicolumn{3}{|c|}{ Orobanche crenata-Ariana } & \multirow[b]{2}{*}{ Mean } \\
\hline & 2009-2010 & 2010-2011 & 2011-2012 & & 2009-2010 & 2010-2011 & 2011-2012 & \\
\hline G1 & $4.8 \mathrm{ab}^{*}$ & $1.9 \mathrm{c}$ & $5.3 \mathrm{c}$ & $4.0 \mathrm{cde}$ & $2.3 \mathrm{bc}$ & $3.2 \mathrm{ab}$ & $0.4 \mathrm{a}$ & $2.1 \mathrm{ab}$ \\
\hline $\mathrm{G} 2$ & $8.1 b$ & $0.2 \mathrm{a}$ & $3.7 \mathrm{bc}$ & $4.0 \mathrm{cde}$ & $2.3 \mathrm{bc}$ & $2.6 \mathrm{ab}$ & $0.1 \mathrm{a}$ & $1.7 \mathrm{ab}$ \\
\hline G3 & $4.8 \mathrm{ab}$ & $0.7 \mathrm{ab}$ & $3.8 \mathrm{bc}$ & $2.9 \mathrm{bcd}$ & $1.4 \mathrm{ab}$ & $1.8 \mathrm{ab}$ & $0.0 \mathrm{a}$ & $1.1 \mathrm{ab}$ \\
\hline G4 & $3.2 \mathrm{ab}$ & $1.7 \mathrm{c}$ & $4.3 \mathrm{c}$ & $3.1 \mathrm{bcd}$ & $1.9 \mathrm{abc}$ & $3.0 \mathrm{ab}$ & $0.4 \mathrm{a}$ & $2.5 \mathrm{ab}$ \\
\hline G5 & $3.2 \mathrm{ab}$ & $1.3 \mathrm{bc}$ & $3.7 \mathrm{bc}$ & 2.7abcd & $0.2 \mathrm{a}$ & $0.5 \mathrm{a}$ & $0.0 \mathrm{a}$ & $0.3 \mathrm{a}$ \\
\hline G6 & $1.9 \mathrm{a}$ & $0.6 a b$ & $0.8 \mathrm{a}$ & $1.1 \mathrm{a}$ & $0.2 \mathrm{a}$ & $0.7 \mathrm{a}$ & $0.0 \mathrm{a}$ & $0.3 \mathrm{a}$ \\
\hline G7 & $1.6 \mathrm{a}$ & $0.6 a b$ & $2.7 \mathrm{abc}$ & $1.6 a b$ & $0.5 \mathrm{a}$ & $3.2 \mathrm{ab}$ & $0.0 \mathrm{a}$ & $1.3 \mathrm{ab}$ \\
\hline 'Baraca' & $6.2 \mathrm{ab}$ & $3.6 \mathrm{~d}$ & $3.6 \mathrm{bc}$ & $4.5 \mathrm{de}$ & $1.2 \mathrm{ab}$ & $6.1 \mathrm{~b}$ & $0.4 \mathrm{a}$ & $3.2 \mathrm{bc}$ \\
\hline ‘Najeh’ & $4.2 \mathrm{ab}$ & $1.4 \mathrm{bc}$ & $1.5 \mathrm{ab}$ & $2.4 \mathrm{abc}$ & $0.7 \mathrm{ab}$ & $2.2 \mathrm{ab}$ & $0.0 \mathrm{a}$ & $1.1 \mathrm{ab}$ \\
\hline ‘Badï’ & $6.8 \mathrm{~b}$ & $5.7 \mathrm{e}$ & $4.5 c$ & $5.7 \mathrm{e}$ & $3.4 \mathrm{c}$ & $4.5 \mathrm{ab}$ & $7.9 \mathrm{~b}$ & $5.2 \mathrm{c}$ \\
\hline
\end{tabular}

Data with the same letter per column are not significantly different according to Duncan's test $(P=0.05)$.

$O$. foetida and $O$. crenata with averages of 1.3 and 1.0 tubercles per plant, respectively (Figure 2$)$. G5 (0.83 g) and G6 (1.1 g) showed the lowest Orobanche attachment dry weights for $O$. crenata, and G2 and G7 infected with O. foetida had 2.3 and $2.6 \mathrm{~g}$, respectively (Table 5). More than $70 \%$ of the parasite attachment reached stage 5 for 'Badi' infested by $O$. foetida, compared with an average of $39 \%$ for the seven tested genotypes; the lowest percent attachment (stage 5) was for the G7 genotype (13.3\%). In the Ariana field infested by $O$. crenata the lowest tubercle stage 5 percentage was for G5 (24\%).
Under high Orobanche infections, the susceptible 'Badi' was the most affected in all cropping seasons compared to other genotypes (Tables 6 and 7). Grain yield of all the new improved genotypes was higher than the partially resistant 'Najeh' at both locations. Genotype G3 $\left(9.9 \mathrm{~g} \mathrm{plant}^{-1}\right)$ gave the highest grain yield under $O$. foetida infestation (Tables 6 and 7) during the three cropping seasons. Under $O$. crenata infestation genotype G5 had the highest seed yield (7.1 g plant $\left.{ }^{-1}\right)$. Nevertheless, G6 presented similar seed production in both Oued Beja and Ariana (7.2 and $7.03 \mathrm{~g} \mathrm{plant}^{-1}$, respectively). The highest

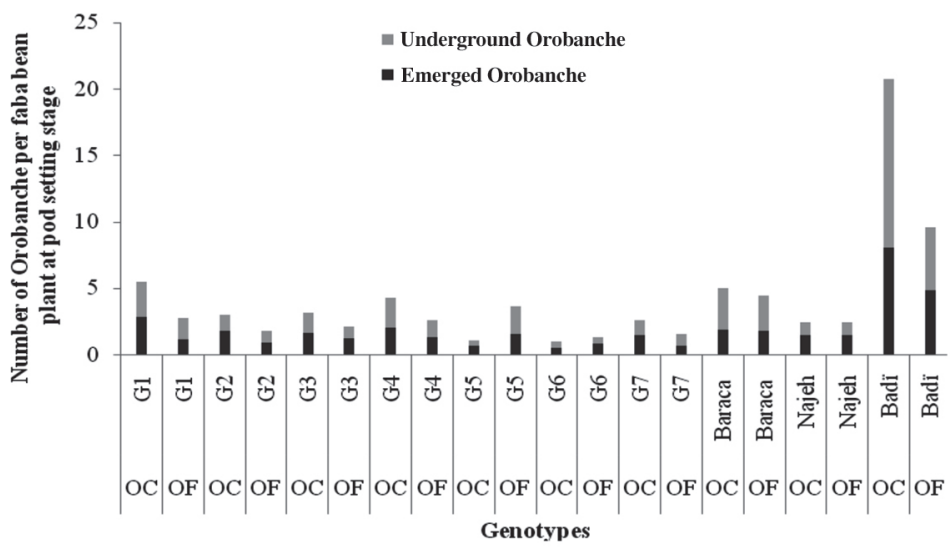

Figure 2. Number of Orobanche (emerged spikes and underground attachments) per faba bean plant in Ariana (OC) and in Oued Beja (OF), Tunisia, at pod setting stage (average of three cropping seasons). 
Table 5. Total Orobanche dry weight (g) per faba bean plant at the beginning of crop maturity for faba bean genotypes during cropping seasons 2009-2010, 2010-2011, and 2011-2012.

\begin{tabular}{|c|c|c|c|c|c|c|c|c|}
\hline \multirow[b]{2}{*}{ Genotypes } & \multicolumn{3}{|c|}{ Orobanche foetida-Oued Beja } & \multirow[b]{2}{*}{ Mean } & \multicolumn{3}{|c|}{ Orobanche crenata-Ariana } & \multirow[b]{2}{*}{ Mean } \\
\hline & $2009-2010$ & 2010-2011 & 2011-2012 & & $2009-2010$ & 2010-2011 & 2011-2012 & \\
\hline G1 & $0.9 \mathrm{a}^{*}$ & $0.8 \mathrm{ab}$ & $13.0 \mathrm{~cd}$ & $4.1 \mathrm{ab}$ & $0.9 \mathrm{~b}$ & $6.2 \mathrm{bc}$ & $0.8 \mathrm{a}$ & $4.2 \mathrm{~d}$ \\
\hline G2 & $0.6 \mathrm{a}$ & $1.4 \mathrm{ab}$ & $7.4 \mathrm{a}$ & $2.6 \mathrm{a}$ & $0.6 \mathrm{~b}$ & $3.6 \mathrm{ab}$ & $0.0 \mathrm{a}$ & $2.9 \mathrm{~cd}$ \\
\hline G3 & $1.6 \mathrm{a}$ & $2.2 \mathrm{abc}$ & $6.1 \mathrm{a}$ & $3.0 \mathrm{a}$ & $2.4 \mathrm{a}$ & $6.4 b c$ & $0.1 \mathrm{a}$ & $3.3 \mathrm{~cd}$ \\
\hline G4 & $1.0 \mathrm{a}$ & $5.8 \mathrm{~cd}$ & $10.6 \mathrm{abc}$ & $4.8 \mathrm{ab}$ & $4.4 \mathrm{~b}$ & $7.0 \mathrm{c}$ & $0.3 \mathrm{a}$ & $4.3 \mathrm{~d}$ \\
\hline G5 & $0.6 \mathrm{a}$ & $2.6 a b c$ & $12.8 \mathrm{bcd}$ & $4.4 \mathrm{ab}$ & $1.3 \mathrm{a}$ & $0.9 \mathrm{a}$ & $0.0 \mathrm{a}$ & $0.8 \mathrm{a}$ \\
\hline G6 & $0.1 \mathrm{a}$ & $1.0 \mathrm{ab}$ & $10.7 \mathrm{abc}$ & $3.2 \mathrm{a}$ & $0.9 \mathrm{a}$ & $2.0 \mathrm{a}$ & $0.1 \mathrm{a}$ & $1.1 \mathrm{ab}$ \\
\hline G7 & 0.0 & 0.0 & $8.8 \mathrm{abc}$ & $2.3 \mathrm{a}$ & $2.2 \mathrm{a}$ & $3.7 \mathrm{ab}$ & $0.3 \mathrm{a}$ & $2.3 b c$ \\
\hline 'Baraca' & $3.7 b$ & $4.8 \mathrm{bc}$ & $12.2 \mathrm{bcd}$ & $6.2 b$ & $2.5 \mathrm{a}$ & $8.0 \mathrm{c}$ & $0.3 \mathrm{a}$ & $3.9 \mathrm{~d}$ \\
\hline ‘Najeh’ & $0.5 \mathrm{a}$ & $2.6 \mathrm{abc}$ & $8.3 \mathrm{ab}$ & $3.1 \mathrm{a}$ & $2.3 \mathrm{a}$ & $5.8 \mathrm{bc}$ & $0.2 \mathrm{a}$ & $3.0 \mathrm{~cd}$ \\
\hline ‘Badï' & $14.0 \mathrm{c}$ & $8.9 \mathrm{~d}$ & $15.6 \mathrm{~d}$ & $13.1 \mathrm{c}$ & $10.1 \mathrm{c}$ & $12.2 \mathrm{~d}$ & $6.0 \mathrm{~b}$ & $9.8 \mathrm{e}$ \\
\hline
\end{tabular}

Data with the same letter per column are not significantly different according to Duncan's test $(P=0.05)$.

Table 6. Grain yield (g plant ${ }^{-1}$ ) for faba bean genotypes during cropping seasons 2009-2010, 2010-2011, and 2011-2012.

\begin{tabular}{|c|c|c|c|c|c|c|c|c|}
\hline \multirow[b]{2}{*}{ Genotypes } & \multicolumn{3}{|c|}{ Orobanche foetida-Oued Beja } & \multirow[b]{2}{*}{ Mean } & \multicolumn{3}{|c|}{ Orobanche crenata-Ariana } & \multirow[b]{2}{*}{ Mean } \\
\hline & $2009-2010$ & 2010-2011 & 2011-2012 & & $2009-2010$ & $2010-2011$ & 2011-2012 & \\
\hline G1 & $8.9 \mathrm{~cd}^{*}$ & $12.6 \mathrm{~b}$ & $6.3 \mathrm{c}$ & $9.3 \mathrm{~cd}$ & $6.1 b$ & $4.3 \mathrm{ab}$ & $9.5 \mathrm{e}$ & $6.3 b c$ \\
\hline G2 & $4.2 \mathrm{abc}$ & $13.0 \mathrm{~b}$ & $5.8 \mathrm{c}$ & $7.6 \mathrm{bcd}$ & $4.9 b$ & $6.4 \mathrm{bc}$ & $5.0 \mathrm{~b}$ & $5.8 \mathrm{bc}$ \\
\hline G3 & $11.2 \mathrm{~d}$ & $13.1 \mathrm{~b}$ & $5.6 \mathrm{c}$ & $9.9 \mathrm{~d}$ & $3.3 \mathrm{ab}$ & $7.0 \mathrm{bc}$ & $8.4 \mathrm{de}$ & $6.2 b c$ \\
\hline G4 & $5.0 \mathrm{abc}$ & $10.5 b$ & $4.0 \mathrm{bc}$ & $6.5 b c$ & $7.1 \mathrm{~b}$ & $4.3 \mathrm{bc}$ & $6.5 \mathrm{bcd}$ & $6.1 b c$ \\
\hline G5 & $3.3 \mathrm{ab}$ & $11.0 \mathrm{~b}$ & $4.6 b c$ & $6.3 b$ & $6.7 \mathrm{~b}$ & $8.9 \mathrm{c}$ & $5.0 \mathrm{~b}$ & $7.1 b c$ \\
\hline G6 & $5.9 \mathrm{bc}$ & $10.0 \mathrm{~b}$ & $5.6 \mathrm{c}$ & $7.2 \mathrm{bc}$ & $6.6 \mathrm{~b}$ & $7.2 \mathrm{bc}$ & $7.3 \mathrm{~cd}$ & $7.0 \mathrm{c}$ \\
\hline G7 & $7.2 \mathrm{bcd}$ & $8.3 \mathrm{~b}$ & $3.9 \mathrm{bc}$ & $6.6 \mathrm{bc}$ & $4.0 \mathrm{ab}$ & $6.2 \mathrm{bc}$ & $6.2 \mathrm{bc}$ & $5.7 b c$ \\
\hline 'Baraca' & $3.0 \mathrm{ab}$ & $8.5 b$ & $3.9 \mathrm{bc}$ & $5.1 \mathrm{~b}$ & $5.4 \mathrm{~b}$ & $6.0 \mathrm{bc}$ & $10.0 \mathrm{e}$ & $7.0 \mathrm{bc}$ \\
\hline 'Najeh' & 4.1abc & $11.1 \mathrm{~b}$ & $1.5 \mathrm{ab}$ & $5.7 b$ & $2.6 \mathrm{ab}$ & $5.3 b c$ & $5.4 \mathrm{bc}$ & $4.6 \mathrm{~b}$ \\
\hline 'Badï' & $0.3 \mathrm{a}$ & $1.4 \mathrm{a}$ & $0.4 \mathrm{a}$ & $0.7 \mathrm{a}$ & $0.1 \mathrm{a}$ & $0.0 \mathrm{a}$ & $1.4 \mathrm{a}$ & $0.5 \mathrm{a}$ \\
\hline
\end{tabular}

Data with the same letter per column are not significantly different according to Duncan's test $(P=0.05)$.

Table 7. One-hundred seed weight (g) for faba bean genotypes during cropping seasons 2009-2010, 2010-2011, and 2011-2012.

\begin{tabular}{|c|c|c|c|c|c|c|c|c|}
\hline \multirow[b]{2}{*}{ Genotypes } & \multicolumn{3}{|c|}{ Orobanche foetida-Oued Beja } & \multirow[b]{2}{*}{ Mean } & \multicolumn{3}{|c|}{ Orobanche crenata-Ariana } & \multirow[b]{2}{*}{ Mean } \\
\hline & 2009-2010 & 2010-2011 & 2011-2012 & & 2009-2010 & 2010-2011 & 2011-2012 & \\
\hline G1 & $61.6 \mathrm{c}^{*}$ & $65.2 \mathrm{c}$ & $55.1 \mathrm{c}$ & $60.6 \mathrm{c}$ & $80.0 \mathrm{~d}$ & $86.2 \mathrm{c}$ & $72.1 \mathrm{c}$ & $80.1 \mathrm{f}$ \\
\hline $\mathrm{G} 2$ & $42.6 \mathrm{ab}$ & $46.0 \mathrm{a}$ & $44.7 \mathrm{ab}$ & $44.4 \mathrm{a}$ & $51.4 \mathrm{~b}$ & $50.8 \mathrm{~b}$ & $53.5 b$ & $51.8 \mathrm{bc}$ \\
\hline G3 & 49.7abc & $60.3 b c$ & $54.1 \mathrm{c}$ & $55.3 \mathrm{bc}$ & $61.6 \mathrm{bcd}$ & $56.6 b$ & $64.4 \mathrm{c}$ & $60.4 \mathrm{~cd}$ \\
\hline G4 & $55.8 \mathrm{bc}$ & $59.9 \mathrm{bc}$ & $47.4 \mathrm{abc}$ & $54.3 \mathrm{bc}$ & $78.0 \mathrm{~d}$ & $63.7 b$ & $81.0 \mathrm{~d}$ & 73.1ef \\
\hline G5 & $40.9 \mathrm{ab}$ & $48.6 \mathrm{a}$ & $41.6 \mathrm{a}$ & $43.7 \mathrm{ab}$ & $55.4 \mathrm{bc}$ & $53.0 \mathrm{~b}$ & $42.0 \mathrm{a}$ & $50.4 \mathrm{bc}$ \\
\hline G6 & $40.5 \mathrm{ab}$ & $41.8 \mathrm{a}$ & $40.2 \mathrm{a}$ & $40.8 \mathrm{a}$ & $51.7 \mathrm{~b}$ & $49.3 b$ & $50.9 \mathrm{ab}$ & $50.5 b c$ \\
\hline G7 & $42.0 \mathrm{ab}$ & $47.2 \mathrm{a}$ & $45.0 \mathrm{ab}$ & $44.7 \mathrm{ab}$ & $49.0 \mathrm{~b}$ & $45.3 b$ & $48.5 \mathrm{ab}$ & $47.4 \mathrm{a}$ \\
\hline 'Baraca' & $57.1 \mathrm{bc}$ & $56.4 \mathrm{~b}$ & $50.9 \mathrm{bc}$ & $54.8 \mathrm{bc}$ & $73.9 \mathrm{~cd}$ & $62.6 \mathrm{~b}$ & $66.5 \mathrm{c}$ & $67.2 \mathrm{de}$ \\
\hline ‘Najeh’ & 49.2abc & $56.3 b$ & $53.4 \mathrm{c}$ & $52.9 \mathrm{bc}$ & $46.9 \mathrm{~b}$ & $58.9 \mathrm{~b}$ & $49.3 \mathrm{ab}$ & $52.4 \mathrm{bc}$ \\
\hline ‘Badï' & $31.5 \mathrm{a}$ & $45.1 \mathrm{a}$ & $44.4 \mathrm{ab}$ & $40.4 \mathrm{a}$ & $24.1 \mathrm{a}$ & $10.5 \mathrm{a}$ & $46.4 \mathrm{ab}$ & $25.3 \mathrm{a}$ \\
\hline
\end{tabular}

Data with the same letter per column are not significantly different according to Duncan's test $(P=0.05)$.

seed weight was recorded for G1 for both Orobanche spp., and the lowest on 'Badi' also for both species. Percent yield reduction from $O$. foetida infestation reached $92.6 \%$ for 'Badï' and the lowest were for G3, G6, and G7 (13.5\%, $28.2 \%$, and $34.9 \%$ ).

There were no significant differences in protein content among genotypes due to Orobanche infestations. Proteins levels in grains were close to $23 \%$ dry weight and did not vary significantly with presence of Orobanche (Figure 3 ).

The behavior of the selected faba bean genotypes was investigated in soil infested by and free of $O$. foetida at Oued Beja, and a field infested with $O$. crenata at Ariana, during three cropping seasons 2009-2010, 2010-2011, and 2011-2012. Several parameters have been used by different authors to evaluate the levels of resistance in infested fields: height of parasitic flowering spikes, weight and number of emerged spikes of Orobanche per host plant, and rate of reproduction (Rubiales et al., 2003b; 2006). Knowing that Orobanche attack is related to growth vigor of the host and competition for resources among attachments (Aalders and Pieters, 1987), indices based only on size and weight of broomrapes can be misleading (Fernández-Aparicio et al., 2007). Thus, Sillero et al. (1996) indicated that the health of the host plant must be considered in Orobanche evaluations, and screening and selection based only on Orobanche emerged number can also be misleading.

In the present study, in addition to the number and weight of emerged shoots of Orobanche per host plant, severity, incidence, and parasitism index were also used to 


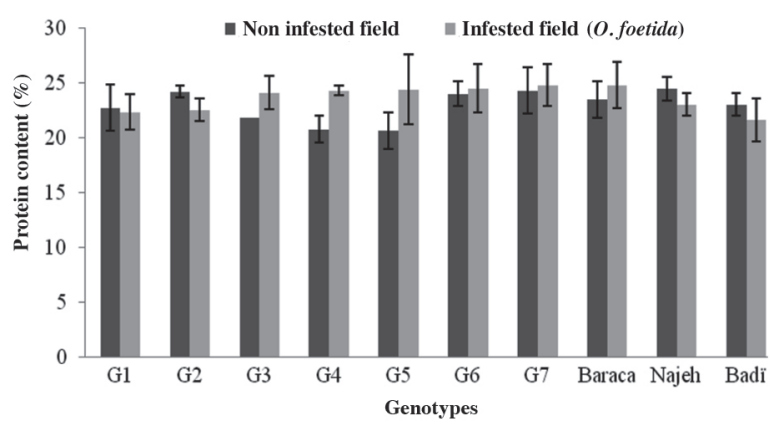

Figure 3. Grain protein content for faba bean genotypes during the cropping season 2009-2010 in fields infested and non-infested with Orobanche foetida.

measure levels of resistance and growth vigor of the host. The degree of attack by the parasite was higher in 'Badi' than other genotypes. The Spanish 'Baraca', developed from the parent 'Giza 402' (Nadal et al., 2004), was still less resistant to $O$. foetida than $O$. crenata compared to resistant 'Najeh' and the seven other lines.

Most of the new genotypes showed few broomrape attachments, especially genotypes G6 and G7 for $O$. foetida and G5 and G6 for O. crenata. Nevertheless, the total number and dry weight of underground and emerged parasites at the two growth stages of the crop were correlated with the resistance level previously established and based on incidence, severity, and parasitism index.

Contrary to the reactions of 'Giza 402' and 'Baraca' infected with $O$. crenata (Nadal et al., 2004), no necrosis of attached tubercles was observed on the new genotypes for both Orobanche species. Similar results were observed by Abbes et al. (2007a; 2007b; 2010b) and no necrosis was reported, confirming that only some mechanisms of resistance of the parent 'Giza 402' against $O$. crenata were observed in our resistant genotypes. The difference in the behavior observed for 'Baraca' infested by $O$. crenata can be attributed to the $O$. crenata population (Román et al., 2002; Abbes et al., 2010b).

Many successes have been reported in breeding for broomrape resistance in faba bean (Fernández-Aparicio et al., 2012; 2014) and several accessions have been developed. In Tunisia, resistance to $O$. foetida has been identified in much faba bean germplasm. 'Najeh', recently registered in 2009 in the Tunisian Varietal Catalogue by INRAT (Kharrat et al., 2010), is characterized by a low number of underground and emerged Orobanche with no parasite necrosis (Abbes et al., 2007a; Kharrat et al., 2010). Its resistance is also related to a deeper root system of the host (Abbes et al., 2007b), to a low soluble invertase activity in $O$. foetida, to a low osmotic potential of the infected roots, and to the organic $\mathrm{N}$ deficiency of the host phloem sap (Abbes et al., 2009a; 2009b). Nevertheless, as reported by Rubiales et al. (2006), only moderate to low levels of incomplete resistance of complex inheritance against parasitic weeds has been identified in other crops, such as in legumes against $O$. crenata, $O$. foetida, and O. aegyptiaca (Kharrat, 2002b; Rubiales et al., 2009; Fernández-Aparicio et al., 2014).

The evaluation of grain productivity per host plant in Orobanche free and infested soil gives more details about the effect of parasitism on hosts. The impact of $O$. foetida infestation on faba bean grain production varied with genotype. Generally, parasitism greatly decreased grain yield, but the partially resistant genotypes were less affected. In non-infested field, 'Badï' was considered a productive cultivar, whereas in infested soils the percentage reduction in grain yield reached $91.7 \%$. In contrast, the productivity of 'Najeh' and other genotypes selected for resistance to $O$. foetida in infested soil was less affected and grain yield reduction was $15.5 \%$ $60 \%$ (Table 8). Losses in seed yield, especially in the first cropping season of 2009-2010, could be related to variations in weather conditions, which are known to influence Orobanche infection and faba bean growth (Rubiales et al., 2003a; Abbes et al., 2010b).

Fetid broomrape did not show significant impact on seed protein accumulation. These observations should be confirmed using grain produced in other cropping seasons. Moreover, Abbes et al. (2007a) observed a decrease in the protein/starch ratio in faba bean plants infected by $O$. foetida and a negative effect of Orobanche attack on nutritional quality of grain. In cowpea parasitized by Striga gesnerioides (Willd.) Vatke or Alectra vogelii Benth., an increase in grain protein content was observed

Table 8. Grain yield ( $\left(\mathrm{p} \mathrm{plant}^{-1}\right)$ and one-hundred seed weight $(\mathrm{g})$ for faba bean genotypes during cropping seasons 2009-2010, 2010-2011, and 2011-2012 in a field not infested by Orobanche at Oued Beja experimental unit.

\begin{tabular}{|c|c|c|c|c|c|c|c|c|c|}
\hline \multirow[b]{2}{*}{ Genotypes } & \multicolumn{3}{|c|}{ Grain yield $\left(\mathrm{g} \mathrm{plant}^{-1}\right)$} & \multirow[b]{2}{*}{ Mean } & \multirow{2}{*}{$\begin{array}{l}\text { Mean } \\
\text { reduction } \\
(\%)\end{array}$} & \multicolumn{3}{|c|}{ One-hundred seed weight (g) } & \multirow[b]{2}{*}{ Mean } \\
\hline & $2009-2010$ & $2010-2011$ & 2011-2012 & & & 2009-2010 & 2010-2011 & 2011-2012 & \\
\hline G1 & $13.8 \mathrm{e}^{*}$ & $18.6 \mathrm{e}$ & $14.8 \mathrm{c}$ & $15.8 \mathrm{~d}$ & 40.9 & $68.5 \mathrm{e}$ & $58.3 \mathrm{~d}$ & $55.7 \mathrm{c}$ & $60.8 \mathrm{~h}$ \\
\hline G2 & $9.7 \mathrm{bcd}$ & $12.1 \mathrm{abc}$ & $13.9 \mathrm{c}$ & $11.9 \mathrm{bc}$ & 35.7 & $51.8 \mathrm{bc}$ & $47.2 \mathrm{bc}$ & $49.2 \mathrm{abc}$ & $49.4 \mathrm{cde}$ \\
\hline G3 & $11.7 \mathrm{de}$ & $11.4 \mathrm{ab}$ & $11.4 \mathrm{abc}$ & $11.5 \mathrm{abc}$ & 13.5 & $56.8 \mathrm{~cd}$ & $52.1 \mathrm{~cd}$ & $53.6 \mathrm{bc}$ & $53.8 \mathrm{efg}$ \\
\hline G4 & $11.0 \mathrm{cde}$ & $16.2 \mathrm{cde}$ & $18.4 \mathrm{~d}$ & $15.2 \mathrm{~d}$ & 56.8 & $62.3 \mathrm{de}$ & $57.2 \mathrm{~d}$ & $55.4 \mathrm{c}$ & $58.3 \mathrm{gh}$ \\
\hline G5 & $5.2 \mathrm{a}$ & 17.0de & $11.9 \mathrm{bc}$ & $11.3 \mathrm{abc}$ & 44.6 & $47.0 \mathrm{ab}$ & $52.2 \mathrm{~cd}$ & $46.5 \mathrm{abc}$ & $48.6 \mathrm{bcd}$ \\
\hline G6 & 8.5abcd & $10.2 \mathrm{a}$ & $11.4 \mathrm{abc}$ & $10.0 \mathrm{ab}$ & 28.2 & $46.5 \mathrm{ab}$ & $40.8 \mathrm{ab}$ & $44.6 \mathrm{ab}$ & $44.0 \mathrm{ab}$ \\
\hline G7 & 7.1ab & $12.5 \mathrm{abc}$ & $10.9 \mathrm{abc}$ & $10.2 \mathrm{ab}$ & 34.9 & $45.7 \mathrm{ab}$ & $42.4 \mathrm{ab}$ & $51.6 a b c$ & $46.6 b c$ \\
\hline 'Baraca' & $11.8 \mathrm{de}$ & 13.6abcd & $13.0 \mathrm{c}$ & $12.8 \mathrm{c}$ & 59.7 & $59.5 \mathrm{~cd}$ & $51.7 \mathrm{~cd}$ & $55.1 \mathrm{c}$ & $55.4 \mathrm{fg}$ \\
\hline ‘Najeh’ & $6.4 \mathrm{ab}$ & $15.4 \mathrm{bcde}$ & $8.2 \mathrm{a}$ & $10.0 \mathrm{ab}$ & 43.1 & $54.0 \mathrm{bcd}$ & $52.2 \mathrm{~cd}$ & 49.4abc & 51.9def \\
\hline ‘Badï' & 7.7abc & $11.7 \mathrm{ab}$ & 7.9a & $9.1 \mathrm{a}$ & 91.6 & $42.0 \mathrm{a}$ & $37.8 \mathrm{a}$ & $41.6 \mathrm{a}$ & $40.4 \mathrm{a}$ \\
\hline
\end{tabular}

Data with the same letter per column are not significantly different according to Duncan's test $(P=0.05)$. 
and could be related to the reduced grain yield in infected plants and, in parallel, to the enhanced $\mathrm{N}$ contents in leaves (Alonge et al., 2001; 2005). Further studies on the effect of broomrape parasitism on protein accumulation in faba bean seeds are suggested.

\section{CONCLUSIONS}

In conclusion, the seven tested genotypes, selected for their partial resistance to Orobanche foetida and $O$. crenata, showed a high level of resistance under field conditions. These genotypes can be promoted as new varieties or used in breeding programs to develop new resistant lines.

\section{ACKNOWLEDGEMENTS}

The authors would like to thank the technical staff at Ariana and Oued Beja (Mrs. Olfa Mlayeh, Mr. Moez Mkademi, Mr. Fadhel Sallemi, and Mrs. Leila Dakhli) for their kind help in conducting the experiments and the Ministry of Agriculture, Ministry of Higher Education, Scientific Research, and Technologies of Information and Communication, and the International Center for Agricultural Research in the Dry Areas ICARDA (European Union-International Fund for Agricultural Development [IFAD] project) for their financial support.

\section{LITERATURE CITED}

Aalders, A.J.G., and R. Pieters. 1987. Resistance in Vicia faba to Orobanche crenata: true resistance versus hidden susceptibility. Euphytica 36:227-236.

Abbes, Z., M. Kharrat, P. Delavault, and W. Chaïbi. 2008. Seed germination and tubercle development of Orobanche foetida and Orobanche crenata in presence of different plant species. Tunisian Journal of Plant Protection 3:101-110.

Abbes, Z., M. Kharrat, P. Delavault, W. Chaïbi, and P. Simier. 2009b. Osmoregulation and nutritional relationships between Orobanche foetida and faba bean. Plant Signal Behavior 4:336-338.

Abbes, Z., M. Kharrat, P. Delavault, P. Simier, and W. Chaïbi. 2007a. Field evaluation of the resistance of some faba bean (Vicia faba L.) genotypes to the parasitic weed Orobanche foetida Poiret. Crop Protection 26:1777-1784.

Abbes, Z., M. Kharrat, P. Delavault, P. Simier, and W. Chaïbi. 2009a. Nitrogen and carbon relationships between the parasitic weed Orobanche foetida and susceptible and tolerant faba bean lines. Plant Physiology and Biochemistry 47:153-159.

Abbes,Z.,M.Kharrat,K. Shaaban, et B. Bayaa.2010b.Comportement de différentes accessions améliorées de féverole (Vicia faba L.) vis-à-vis d'Orobanche crenata Forsk. et Orobanche foetida Poir. Cahiers Agricultures 19:194-199.

Abbes, Z., M. Kharrat, P. Simier, and W. Chaïbi. 2007b. Characterization of resistance to crenate broomrape (Orobanche crenata) in a new small seeded line of Tunisian faba beans. Phytoprotection 88:83-92.

Abbes, Z., F. Sellami, M. Amri, and M. Kharrat. 2010a. Effect of sowing date on Orobanche foetida infection and seed yield of resistant and susceptible faba bean cultivars. Acta Phytopathologica et Entomologica Hungarica 45:267-275.

Alonge, S.O., S.T.O. Lagoke, and C.O. Ajakaiye. 2001. Cowpea reactions to Alectra vogelii II: effect on yield and nutrient composition. Crop Protection 20:291-296.
Alonge, S.O., S.T.O. Lagoke, and C.O. Ajakaiye. 2005. Cowpea reactions to Striga gesnerioides. II. Effect on grain yield and nutrient composition. Short communication. Crop Protection 24:575-580.

AOAC. 1975. Official methods of analysis of AOAC International. $12^{\text {th }}$ ed. In William Horwitz (ed.) Association of Official Analytical Chemists (AOAC), Washington, D.C., USA.

Díaz-Ruiz, R.,A. Torres, M.V. Gutierrez, D. Rubiales, J.I. Cubero, M. Kharrat, et al. 2009. Mapping of quantitative trait loci controlling Orobanche foetida Poir. resistance in faba bean (Vicia faba L.) African Journal of Biotechnology 8:2718-2724.

El-Shirbini, E.H., and O. Mamdouh. 2004. Integrated management of Orobanche in food legume systems: The Egyptian experience in IPM of Orobanche, Nile Valley and Red Sea Program. p. 32-54. In Dahan, R., and M. El-Mourid (eds.) Integrated management of Orobanche in food legumes in the Near East and North Africa. Proceedings of the Expert Consultation on IPM for Orobanche in Food Legume Systems in the Near East and North Africa. ICARDA/INRA/FAO, Rabat, Morocco.

Fernández-Aparicio, M., T. Kisugi, X. Xie, D. Rubiales, and K. Yoneyama. 2014. Low strigolactone root exudation: A novel mechanism of broomrape (Orobanche and Phelipanche spp.) resistance available for faba bean breeding. Journal of Agricultural and Food Chemistry 62:7063-7071.

Fernández-Aparicio, M., A. Moral, M. Kharrat, and D. Rubiales. 2012. Resistance against broomrapes (Orobanche and Phelipanche spp.) in faba bean (Vicia faba) based in low induction of broomrape seed germination. Euphytica 186:897-905.

Fernández-Aparicio, M., A. Pérez-de-Luque, M.D. Lozano, and D. Rubiales. 2007. Inoculation and growth with root parasitic weeds. In Mathesius, U., E.P. Journet, and L.W. Sumner (eds.) The Medicago truncatula handbook. Samuel Roberts Noble Foundation, Ardmore, Oklahoma, USA.

Joel, D.M., J. Hershenhorn, H. Eizenberg, R. Aly, G. Ejeta, P.J. Rich, et al. 2007. Biology and management of weedy root parasites. Horticultural Reviews 33:267-350.

Kharrat, M. 1999. Orobanche research activities on faba bean in Tunisia. p. 77-81. In Cubero, J.I., M.T. Moreno, D. Rubiales, and J.C. Sillero (eds.) Resistance to broomrape, the state of the art. Junta de Andalucia, Sevilla, Spain.

Kharrat, M. 2002a. Etude de la virulence de l'écotype de Béja d'Orobanche foetida sur différentes espèces de légumineuses. p. 89. In Kharrat, M., F. Abbad Andaloussi, M.E. Maatougui, H. Sadiki, W. Bertenbreiter (eds.) Devenir des légumineuses alimentaires dans le Maghreb. GTZ, Tunis, Tunisia.

Kharrat, M. 2002b. Sélection de lignées de féverole, résistantes à l'Orobanche foetida. p. 92. In Kharrat, M., F. Abbad Andaloussi, M.E. Maatougui, H. Sadiki, W. Bertenbreiter (eds.) Devenir des légumineuses alimentaires dans le Maghreb. GTZ, Tunis, Tunisia.

Kharrat, M., Z. Abbes, and M. Amri. 2010. A new faba bean small seeded variety Najeh tolerant to Orobanche registered in the Tunisian catalogue. Tunisian Journal of Plant Protection 5:125130.

Kharrat, M., and M.H. Halila. 1994. Orobanche species on faba bean (Vicia faba L.) in Tunisia: Problem and management. p. 639643. In Pieterse, A.H., J.A.C. Verkleij, and S.J. ter Borg (eds.) Biology and management of Orobanche: Proceedings of the Third International Workshop on Orobanche and Related Striga Research, Amsterdam. 8-12 November 1993. Royal Tropical Institute, Amsterdam, The Netherlands.

Kharrat, M., and T. Souissi. 2004. Research on Orobanche foetida and O. crenata in Tunisia. p. 106-110. In Dahan, R., and M. ElMourid (eds.) Proceedings of the Expert Consultation on IPM for Orobanche in Food Legume Systems in the Near East and North Africa. ICARDA/INRA/FAO, Rabat, Morocco ICARDA/INRA/ FAO, ICARDA, Aleppo, Syria.

Labrousse, P., M.C. Arnaud, H. Serieys, A. Bervillé, and P. Thalouarn. 2001. Several mechanisms are involved in resistance of Helianthus to Orobanche cumana Wallr. Annals of Botany $88: 859-868$ 
Maalouf, F., S. Khalil, S. Ahmed, A.N. Akintunde, M. Kharrat, K. El Shama'aa, et al. 2011. Yield stability of faba bean lines under diverse broomrape prone production environments. Field Crop Research 124:288-294.

Nadal, S., M.T. Moreno, and J.I. Cubero. 2004. Registration of 'Baraca' faba bean. Crop Science 44:1864-1865.

Parker, C. 2012. Parasitic weeds: A World challenge. Weed Science 60:269-276.

Pérez-de-Luque, A., H. Eizenberg, J.H. Grenz, J.C. Sillero, C. Avila, J. Sauerborn, et al. 2010. Broomrape management in faba bean. Field Crop Research 115:319-328.

Pérez-de-Luque, A., J.C. Sillero, A. Moral, J.I. Cubero, and D. Rubiales. 2004b. Effect of sowing date and host resistance on the establishment of Orobanche crenata in faba bean and common vetch. Weed Research 44:282-288.

Román, B., Z. Satovic, D. Rubiales, A.M. Torres, J.I. Cubero, N. Katzir, et al. 2002. Variation among and within populations of the parasitic weed Orobanche crenata from Spain and Israel revealed by inter simple sequence repeat markers. Phytopathology 92:1262-1266
Rubiales, D., C. Alcántara, A. Pérez-de-Luque, J. Gil, and J.C. Sillero. 2003a. Infection of chickpea (Cicer arietinum) by crenate broomrape (Orobanche crenata) as influenced by sowing date and weather conditions. Agronomie 23:359-362.

Rubiales, D., A. Pérez-de-Luque, J.I. Cubero, and J.C. Sillero. 2003b. Crenate broomrape (Orobanche crenata) infection in field pea cultivars. Crop Protection 22:865-872.

Rubiales, D., A. Pérez-de-Luque, M. Fernández-Aparicio, J.C. Sillero, B. Román, M. Kharrat, et al. 2006 Screening techniques and sources of resistance against parasitic weeds in grain legumes. Euphytica 147:187-199.

Rubiales, D., M. Fernández-Aparicio, A. Pérez-de-Luque, E. Prats, M.A. Castillejo, J. Sillero, et al. 2009. Breeding approaches for crenate broomrape (Orobanche crenata Forsk.) management in pea (Pisum sativum L.) Pest Management Science 65:553-559.

Sillero, J.C., D. Rubiales, and J.I. Cubero. 1996. Risks of Orobanche resistance screening based only on number of emerged shoots per plant. p. 651-657. In Moreno, M.T., J.I. Cubero, D. Berner, D. Joël, L.J. Musselman, and C. Parker (eds.) Proceedings of the Sixth International on Parasitic Weed Symposium, Cordoba. 1618 April 1996. Advances in Parasitic Plant Research, Cordoba, Spain. 